\title{
WORKING-CLASS STANDARDS OF LIVING IN THREE LANCASHIRE TOWNS, 1890-1914
}

This article examines some aspects of working-class standards of living in three Lancashire towns, Barrow-in-Furness, Lancaster and Preston, in the period 1890 to 1914 . By looking on one hand at a number of externally determined factors, such as real wages and the cost of living, and on the other at the strategies with which the working-class families attempted to maximise their standards of living, an assessment is made of the relative success of these various strategies, particularly at periods when wages were on or below the poverty line. Particular stress is laid on evidence from Preston, in part because it has not previously been reported, ${ }^{1}$ but also because there appear to be a number of significant variations between Preston on the one hand, and Barrow and Lancaster on the other, when placed in apparently similar intrinsic conditions and in comparatively close geographical proximity to each other. These variations underline the extent to which generalisations derived principally from statistical data may be misleading, and also the importance of looking at individual discrete communities before relying on theoretical models of the relationship between, for example, income from primary employment and standards of living. If it is possible to demonstrate that working-class people in some towns were more successful than their near neighbours in combating poverty, we need to identify the reasons for these differences. Factors discussed include the economy of Preston compared with Barrow and Lancaster, comparisons of wage rates, the employment of women and its effects, and diets (including the use of allotments), the effects of drinking, as well as a look at possible negative factors, such as family size, and housing and hygiene.

1 E. Roberts, "Working-Class Standards of Living in Barrow and Lancaster, 1890-1914", in: Economic History Review, Second Series, XXX (1977). This article placed particular emphasis on the importance of women's part-time casual earnings, the choice of an economical and nutritious diet, and the importance of the working-class habit of living off the land. 
Both documentary and oral evidence are used, and are tested throughout to see which can provide the clearer and fullest insight into working-class standards of living. As will be shown below, however, it is the oral evidence which can often supply information, e.g., about supplementation of diets, which is elusive or non-existent in the documentary evidence, particularly since the latter is invariably of an official and cumulative rather than a personal and individual nature. Oral evidence is also crucial, it is suggested, for the understanding of the perceptions of the working-class families themselves about what were tolerable or sustainable levels of daily existence. 156 elderly people were interviewed in depth in the three towns, thereby establishing a substantial fund of data. This article is necessarily highly selective in the use of these data, but since the selection is the culmination of an extended process of codifying and indexing the evidence, the illustrations used below are in all cases typical of a very much greater number of examples which could be cited.

The question of working-class standards of living had already aroused a considerable amount of interest in the quarter of a century between 1890 and the beginning of the First World War. Doctors, philanthropists, social scientists and politicians studied this complex and controversial subject from differing philosophical bases and with differing premises, and not surprisingly tended to differ in their conclusions about the causes of working-class poverty. ${ }^{2}$ Probably the best-known official report, and most effective in the terms of resulting legislation, was that of the Inter-Departmental Committee on Physical Deterioration (established to investigate why as many as 60 per cent of volunteers for the Boer War, in certain areas, were rejected on medical grounds). This was perhaps the most censorious of the reports of the period, being highly critical of working-class patterns of expenditure, consumption and diet. It stated, for example, that the poor could have obtained a better diet in terms of calories and nutrients if less had been spent on animal protein: "It is no doubt the case that with greater knowledge the poor might live more cheaply than they do." 3 The best known surveys undertaken by individuals were B. S. Rowntree's Poverty: $A$ Study of Town Life, published in 1901, in which he studied working-class standards of living in York, and Maud Pember Reeves's Round About a Pound a Week (1913), in which she and other members of the Fabian

2 Some of the published studies are Family Budgets, Being the Income and Expenses of Twenty-Eight British Households 1891-4 (London, 1896); D. N. Paton, J. C. Dunlop and E. Inglis, A Study of the Diet of the Labouring Classes in Edinburgh (Edinburgh, 1902); J. Oliver, "The Diet of Toil", in: Lancet, 29 June 1895.

${ }^{3}$ Inter-departmental Committee on Physical Deterioration [Cd 2175] (1904), p. 224. 
Women's Group recorded the daily budgets and lives of working-class families in Lambeth. ${ }^{4}$ These various individual surveys were based on small samples in specific areas, and the value of such local or regional studies as these lies in the delineation of the significant differences in working-class standards of living between one area and another, and indeed between one town and another, ${ }^{5}$ a difference which continues in the present sample of three towns.

Rowntree, in his seminal study of York, suggested on the basis of a close study of the budgets of 26 working-class families, that it was possible to draw a poverty line at $21 / 8 \mathrm{~d}$ for a family of four to five persons. Any family whose total weekly income was less than this was in primary poverty; that is, "earnings insufficient to obtain the minimum necessaries for the maintenance of merely physical efficiency". It is very interesting to compare Rowntree's work with the three towns in the present survey, ${ }^{7}$ in which no unskilled labourer in the pre-First-World-War period earned in money wages as much as $£ 11 / 8 \mathrm{~d}$, and the real wages even of skilled men could be reduced to this level in years of strikes, lock-outs or slumps. The same disasters, of course, also reduced the real wages of labourers to a level well below the poverty line.

The three towns were founded on different economic bases, and represent a wide cross-section of English urban provincial life in the last decade of the nineteenth century and the first one of the twentieth. Barrow was predominantly a town of heavy industries: in 1911, 37.5\% of the workforce was employed by the firm of Vickers either in the construction of ships or in heavy engineering, while another $7 \%$ were iron and steel work-

4 B. S. Rowntree, Poverty: A Study of Town Life (London, 1901); M. P. Reeves, Round About a Pound a Week (London, 1913).

5 The need for regional and local studies of standards of living has been suggested by, inter alia, T. S. Ashton, "The Standard of Life of the Workers in England, 1790-1830", in: Capitalism and the Historians, ed. by F. A. Hayek (Chicago, 1954); R. S. Neale, "The Standard of Living 1780-1844: A Regional and Class Study", in: Economic History Review, Second Series, XIX (1966); G. J. Barnsby, "The Standard of Living in the Black Country During the Nineteenth Century", ibid., XXIV (1971); and M. W. Flinn, "Trends in Real Wages, 1750-1850", ibid., XXVII (1974).

6 Rowntree, Poverty, op. cit., p. 296.

7 Research into working-class family and social life in Barrow and Lancaster was supported by an SSRC grant in the period 1974-76. Similar research in Preston was supported by an SSRC grant in the period 1978-81. The research has used both documentary and oral evidence. In the three towns, 156 old people were interviewed in depth and the indexed transcriptions are available for use in the University of Lancaster library. The work has been carried out under the aegis of the Centre for North-West Regional Studies in the University of Lancaster and with considerable help from the staff, especially Marion McClintock, without whom this article would not have been written. 
ers. ${ }^{8}$ Preston was a cotton town: in $1911,45 \%$ of its working population were textile workers; the next-largest group were those engaged in engineering and machine making, but these formed only $5 \%$ of the workforce. ${ }^{9}$ Lancaster too had one major industry, the manufacture of oil cloth and linoleum (with its associated cotton mills which provided the backing for the oil cloth). In 1911,30\% of the workforce was thus employed.$^{10}$ Much of the rest of Lancaster's population was in some form of service industry, either in retailing or within an institution (Lancaster having a large mental hospital, a subnormality hospital and a prison which catered for a very large catchment area, as well as its own local hospital). Only in Barrow was there a significant body of skilled craftsmen, although it is impossible to deduce from the census returns exactly what percentage of the labour-force they represented. ${ }^{11}$

Wage levels are of obvious and fundamental importance in any consideration of living standards, and this is where the interesting differences between the three towns come into play. Firstly, there is little difficulty in discovering, from oral evidence, the rates of pay for the unskilled in Barrow and Lancaster, which varied from $18 /-$ a week to $f 13 d$. It can be presumed that respondents are as clear and consistent about these figures as they have been found to be, because the rates were regular and unchanging over comparatively long periods (although, as has already been mentioned, real wages could and indeed were less in periods of strikes, lock-outs and unemployment). It has proved much more difficult to establish similar rates in Preston; respondents are unclear, the local press is silent and, most surprising of all, there are few references in existing union reports. As far as the labourers were concerned, whether occupied on the docks, on a building site or on a farm, their wages appear to have been both irregular and low. The only firm documentary evidence is the Board of Trade Enquiry of 1905, which is in itself confusing; engineering labourers' wages are given as being between $17 /-$ and $19 /-$ a week, but those for building labourers between $22 /-$ and $26 /-$ a week (which are higher figures than those given in oral evidence). Elsewhere in the report, however, is the statement: "In a few cases the rate for adult able-bodied men was as low as $14 \mathrm{~s}$, but for the majority of the labourers employed in the

8 Census of 1911 , County of Lancaster, table 23. The Census does not of course mention Vickers, but in Barrow it can be safely assumed that those enumerated under General Engineering and Ships and Boats worked for the company.

9 Ibid., table 13.

10 Ibid., table 24.

11 It can be sensibly argued that textile weavers were highly skilled workers. They did not, however, serve a recognised apprenticeship, nor were they paid at a skilled man's rate. 
Table 1. Labourers' wages in 1905

London $=100$

Building labourers

Engineering labourers

Barrow

98

82

Preston

84

75

Source: Board of Trade Enquiry, op. cit., pp. xxiv-xxv.

town the rate coincided with that quoted for the engineering trade, viz., 17s to 19 s per week." 12 Both the oral and documentary evidence indicates that although unskilled wages in Barrow and Lancaster were below 21/8d (Rowntree's poverty line), labouring wages were lower still in Preston, and that this is one very obvious reason for there being a lower standard of living in Preston.

As has been seen, the "typical" worker in Preston of either sex was a textile worker and unlike the labourers, they earned, according to the Board of Trade Enquiry, wages which put them firmly above the poverty line (a weaver was given as earning $22-28 /$ - per week). Both oral and documentary evidence would indicate, however, that textile wages were both low and irregular. Weavers' earnings were calculated according to the length of the "cut" woven, its width, the number of threads to the square inch, the fineness of the yarn and the complexity of the pattern. Wages were affected by the mechanical reliability of the loom, the technical competence of the tackler and the availability of new "beams". There are no wage rates given in the records of the Weavers, Winders and Warpers Association, only occasional case-histories. In 1906, one William Wilson complained not about his low wages, but about losing his job unfairly. His previous three weeks' earnings as a three-loom weaver were given as $16 /-$, $15 / 6 \mathrm{~d}$ and $15 /-.{ }^{13}$ In 1910, winders, depending on the "twist" of the yarn they worked with, earned between $12 /-$ and $22 /-$ a week. ${ }^{14}$ The "aristocrat" of the mill was the mule spinner whom the Board of Trade quoted as earning between $35 /-$ and $43 /-$. But these were the wages of the men in charge of the mule. Those who worked with him on the mule earned

12 Board of Trade Enquiry into Working-Class Rents, Housing and Retail Prices (1908), Town Reports [Cd 3864], p. 381.

13 Preston and District Power-Loom Weavers, Winders and Warpers Association, Cases and Complaints Book, 1904-09, Preston Record Office DDX 1089811.

14 Preston and District Power-Loom Weavers, Winders and Warpers Association, Wages Calculation Book, 1900-45, Preston Record Office DDX 10891411. 
substantially less, usually under $\mathfrak{E l}$; as they were paid directly by the mule spinner, it is difficult to find documentary evidence of actual payments. ${ }^{15}$

Closely allied with wages are, of course, prices, for which the Board of Trade Enquiry gives the data (see Table 2). This indicates that the lower wages in Preston were to some extent compensated for by lower prices and lower rents than in Barrow. Unfortunately, as with all price indices, the food listed was not necessarily that purchased by the inhabitants. There were many factors, not discussed by the Board of Trade Enquiry, which pushed up the cost of living in Preston (see below). The existence of low wage rates in Preston as compared with Barrow (and also with Lancaster, according to oral evidence) means that it is both important and of considerable interest not only to examine which strategies the Prestonians in particular adopted, but also to compare the relative success of these strategies with those adopted in Barrow and Lancaster.

A crucial factor in any study of standards of living in Preston is the extensive full-time employment of women, for there are marked differences in this respect between Preston and the other two towns (see Table 3 ). The obvious explanation for the high percentage of married women in work in Preston of course is the availability of jobs in the textile industry. For almost a century the labour market in the textile areas had needed large numbers of women workers, and the vast majority of Preston working women supplied that need (71\% in 1901 and $76 \%$ in 1911). They were usually weavers, but also carders, winders and ring spinners. Women weavers were paid at the same rate as men and therefore a woman textile worker could double her family wages. Yet the exigencies of the labour market and attractively high wages are not the reasons given by women who went to work in the mills. They regarded their obligation to work as an indication of poverty and a sign that their husbands' wages were inadequate to support a family, the only exceptions being the small minority of shopkeepers.

Life wasn't easy. [...] my grandmother looked after me in my early days when father and mother went out to work, $[\ldots]$ you had to go to work otherwise you didn't live. ${ }^{16}$

For women with husbands on low wages it seemed that choosing mill work was the best strategy to ensure that they balanced their families' budgets. They certainly earned more than women doing part-time domestic work:

15 Mrs H.2.P., born 1898, claimed that her father, as a piecer, earned $16 / 10 \mathrm{~d}$. This was increased to $£ 2$ when he became a minder in about 1903 .

$16 \mathrm{Mr}$ T.2.P., born 1902, p. 4. 
Table 2. The Board of Trade Enquiry into Working-Class Rents, Housing and Retail Prices (in 1905)

Rents and prices, Rents index Prices index combined index

$\begin{array}{lrrr}\text { London } & 100 & 100 & 100 \\ \text { Barrow } & 92 & 63 & 99 \\ \text { Preston } & 82 & 48 & 90\end{array}$

Source: Board of Trade Enquiry, pp. 1-li.

Table 3. Full-time employment of married and widowed women

$\begin{array}{lrl} & 1901 & 1911 \\ \text { Barrow } & 5.8 \% & 6.9 \% \\ \text { Lancaster } & 10.2 \% & 11 \% \\ \text { Preston } & 30.5 \% & 35 \%\end{array}$

Source: Census of 1901, County of Lancaster, table 35a; Census of 1911, County of Lancaster, table 25 .

cleaners earned $2 /$ - to $2 / 6 \mathrm{~d}$ a day, for example, although hours and pay varied considerably from employer to employer. It is, however, perhaps misleading to discuss "a choice of strategy", because necessarily a Prestonian's choice was conditioned by the demands of the labour market, and a century of working-class traditions and neighbourhood practices.

It is clear, however, from the oral evidence that an individual woman's full-time wage did not have quite the beneficial effect on her family's standard of living that might be anticipated. A woman textile worker usually continued working after marriage, ceasing work only if 1) her family became too large (usually more than four children), 2) her husband obtained a better paid job, or 3 ) her older children began themselves to earn and to contribute to the family budget. She carried some necessary and quite substantial expenses. Any small children had to be minded, as mill hours were from 6 a.m. to 5.30 p.m. (with $1 \frac{1}{2}$ hours for meals). The child minder was always paid, the amounts quoted varying from $3 /-$ to $10 /-{ }^{17}$ per week per child, and thus the cost of paying for only two children

${ }_{17}$ Mrs T.3.P., born 1912, 3/- per child c. 1916; Mr T.3.P., born 1886, 10/- per child c. 1912 for his own children. There are many other examples. 
to be minded would take a substantial part of a woman's weekly wages. Furthermore, many full-time working wives had to rely on some convenience foods, such as bought bread, fish and chips, potato pies (with a little meat) and tripe. It is the children whose mothers were not textile workers who are most scathing about the "textile diet".

For food they simply took a basin to the chip shop and leave it. They would pick it up at dinner-time and it would be ready for them [. . . ] or they would take it to a place where they sold pies, or where they cooked meat and that would be their meal. ${ }^{18}$

They absolutely lived on fish and chips and meat and potato pies and believe you me, they are the dearest meal that any housewife can buy. ${ }^{19}$

The evidence from the families of textile workers themselves is rather more complex; their children may well have had a more varied diet if they had their meals with a relation or child minder and moreover some highly organised, very hard working textile women did manage some home cooking. Yet the temptation to buy ready-cooked food was strong. "She went to work and she couldn't cook." 20 "I never remember my mother cooking." 21

This textile diet was not necessarily unnutritious, but it was monotonous and it conspicuously lacked vegetables and fruit, and it was also more expensive than home-made food. One old man calculated that pies cost $2 \mathrm{~d}$ before the First World War and that his family needed eight per meal, which came to $1 / 4 \mathrm{~d}$. He claimed that a home-made hotpot would cost about half that and would provide better and more substantial food. Throughout this period there was a steady increase in the number of convenience food shops in Preston. In 1892, there was one fish-and chip shop to every 1,533 people. By 1907 , they had virtually doubled to one to every 785 . In the same period the number of confectioners (selling pies and cakes) increased from one to 853 people to one to 472 people. In the same period the number of butchers' shops fell from one to 672 people to one to 813 people. ${ }^{22}$

Oral evidence indicates that although families where the mother worked part-time did not rely on these shops to the same extent as fulltime-working women, it can be shown that they used them more than families in either Lancaster or Barrow, and that their food budgets could

$18 \mathrm{Mr}$ W.3.P., p. 19.

19 Mr F.1.P., p. 61.

20 Miss A.3.P., p. 10. This lady did cook when she gave up full-time work.

21 Mr B.9.P., p. 8.

22 Barratt's Directory of Preston and District, 1892 and 1907. 
Table 4

\section{Amount spent per Co-op member in 1905}

Amount spent at
Co-op per head of
population in 1905

$£ 4$

$£ 4$

$£ 3$

Source: Fifty Years of Co-operatives in Lancaster (Lancaster and Skerton Equitable Industrial Co-operative Society Ltd, Lancaster, 1910); Barrow Co-operative Society Limited (Barrow Cooperative Society, Barrow, 1910); Report on Industrial and Agricultural Co-operative Societies in the United Kingdom [Cd 6045] (1912).

thus well have been higher or the total amount of food consumed less. ${ }^{23} \mathrm{~A}$ married textile worker often found shopping difficult, for her hours of work and the pressure of housework meant that she usually relied on shopping in her own locality. The more fortunate or far-sighted used their local Co-ops, which were able to return a dividend. It is clear, however, from oral evidence that poorer Prestonians, that is those in the inner city areas, were less likely to use their Co-ops than were more prosperous Prestonians on the outer fringes of the towns, or than either Barrovians or Lancastrians. In 1905, 15\% of Preston's population were members of the Co-op, the same percentage as in Barrow. In Lancaster, however, 26\% of the population belonged to the Co-op. It is in the amounts spent where there are differences between the towns (see Table 4). The majority of textile workers relied on small local shops, which had the disadvantage of high prices, but the essential advantage of giving credit. This was necessary for many women, whether working outside the home or not, because of the irregular nature of their family's budget.

A lot of them had shop books [. . . ] they called them Belly Bibles. These little cornershops they were gold mines because their prices were sky-high. ${ }^{24}$

Full-time-working wives not only had to pay more for their food, but also for their clothing. Some, who could not face the prospect of boiling, pounding, rinsing and mangling their clothes after a day in the mill, would pay their neighbours $1 /-$ to $2 / 6 \mathrm{~d}$ a bundle to be washed. They also had little time to make their family's clothes. One woman said that her family had a sewing machine, but "We hardly ever used it. I think it was only there

23 Roberts, "Working-Class Standards of Living", loc. cit., p. 314.

24 Mr G.1.P., p. 69. 
for the article."25 Another respondent claimed that her mother made her polish the machine, but refused to tell her how to use it. Because there was so little time to make clothes at home, full-time working women did not have the sense of enjoyment and satisfaction expressed by other women of "making something out of nothing". In the absence of these feelings some women seemed to go to the other extreme and display quite strong feelings that somehow home-made clothes were something to be ashamed of. Some families relied on second-hand clothes for their children and then, as soon as could be afforded, went off to the dressmaker or clothing store. The symbols of the Prestonian devotion to conspicuous spending on clothing can be seen in the annual Whit Monday religious processions, when tens of thousands of children (and adults) walked through Preston. Each church chose its own children's clothes; these were often beautiful, but equally often quite impractical. The social and religious solidarity displayed on these occasions is admirable, but the effect on working-class budgets would be less than beneficial. This determination to have bought clothes could be regarded as a sign of affluence, but combined with low wages it must also be presumed to have further reduced the proportion of the budget spent on food.

There were therefore many unquantifiable costs incurred when a married woman worked full-time, which much reduced her real income. It is possible, of course, to argue that although the individual woman worker and her nuclear family did not derive the complete benefit of a second income, her earnings nevertheless augmented the income and thereby improved the standard of living of many others, for she in turn gave paid employment to child minders, washer-women and the proprietors of both convenience food and corner shops, thus redistributing income around a wider group and marginally enhancing the standard of living of a whole community. There was, however, another incalculable effect of a married woman's working full-time. Oral evidence indicates the tremendous burden of work carried by these women. "It was all bed and work" is a phrase which constantly recurs in the evidence. One woman's evidence relates to the 1920's and is chosen because it is first-hand rather than being an account of her mother's life, but it could equally well have applied to the pre-First-World-War period:

I'd be washing at 1 o'clock in the morning and getting up at 5 o'clock to go to work. ${ }^{26}$

25 Mrs B.2.P., pp. 26-27.

26 Mrs W.1.P., p. 8. 
This ceaseless round of heavy physical work, both in the mill and in the home, must have had a detrimental effect on the textile women's health and, indeed, on that of their husbands, because it is clear that whereas men whose wives stayed at home or who worked only part-time, on the whole, helped with housework infrequently or not at all, men with full-timeworking wives did a lot of household chores, including cooking and cleaning. It is, of course, impossible to estimate on any quantifiable basis what the effects of such strenuous regimes might be, but it would seem likely that part of the death rate in Preston was caused by exhaustion; the stated cause of death may have been pneumonia or bronchitis or influenza, but the underlying reason was the fact of the patient's being totally worn out, and worked almost literally to death.

The existence of a large number of married women in full-time textile work had still another ironical but important effect on the general standards of living in their community. It is reasonably clear that the presence of large numbers of women in the mills tended to depress textile wage rates. $\mathrm{E}$. $\mathrm{H}$. Hunt commented on this phenomenon with reference to both the cotton and the woollen textile industries:

The female weavers who worked with men for identical rates were among the highest-paid women workers in Britain whereas male weavers were badly paid compared with men. If the women gained from doing work that was not unequivocally women's work, the men [...] clearly lost something by competing in an occupation where pay was affected by the prevailing level of women's wages. ${ }^{27}$

The Preston Weavers, Winders and Warpers Association, although having many members, was remarkably unmilitant about wage rates, confining its attention to the fixing of prices for the production of various types of cloth or yarn. Many of the members were women, who appear to have been totally uninterested in its affairs, and simply paid their small subscription as a kind of insurance against the day when they might have found themselves in dispute with the management. Apart from the fact that this lack of militancy may have helped keep textile wages at a depressed level, it seems probable that the existence of a large number of textile-working wives had an effect on labouring rates in the wider local area. This was certainly the view expressed by the Pilgrim Trust for the inter-war period. Writing especially of Blackburn (which is only nine miles from Preston and economically very similar), their report states: 
Table 5. Wages indices in Lancashire in 1905

London $=100$

Three towns with over $30 \%$ of married women in employment (Blackburn, Burnley, Preston)

Seven towns with under $20 \%$ of married women in employment Mean for Lancashire and Cheshire

Mean building labourers' wages
Mean engineering labourers' wages

Source: Board of Trade Enquiry, p. xxxiv.

Wages have always been fixed in Blackburn on the assumption that several members of the family will be working.

Wages in most of the Lancashire cotton towns assume the double earnings of man and wife. The husband's wages alone would reduce many families into poverty, and it is consequently necessary for the wife to earn all the time. $^{28}$

The evidence from before the First World War would appear to support this argument. The Board of Trade Enquiry gave wage indices for the major industrial towns in Lancashire (see Table 5). While it is impossible to prove the exact connection between the existence of a high percentage of employed married women and general wage rates, it is evident that they did not produce high rates, at least in Lancashire. The exigencies of the labour market in Preston meant, therefore, that many married women had to go to work because of their husbands' low wage rates; unhappily and of course unwittingly, their labour may well have in turn helped produce those same low rates.

There were, of course, in Preston, as in Barrow and Lancaster, married women who had part-time jobs (in the samples about $40 \%$ in Preston, 50\% in Barrow and $40 \%$ in Lancaster). In general these women did a limited range of domestic work, cleaning, working, washing or sewing and child minding. They were paid less than those in full-time work, but they gained by not having to pay for child minders, convenience foods or bought clothing, and they had more time to make the nutritious and economical broths, stews and hotpots so frequently mentioned in Barrow and Lan-

28 Men Without Work. A Report made to the Pilgrim Trust (Cambridge, 1938), pp. 85, 235 . 
caster. There is, in fact, no overwhelming evidence that Lancashire women in textile towns did not know to cook, as so many critics have believed. ${ }^{29}$ Some had mothers who had never been textile workers and had therefore been able to teach them the arts of traditional cooking; others, whose mothers had been textile workers, speak of learning from the grandmother or aunt who brought them up; and once women stopped working full-time they would and did begin to cook. The families, however, of mothers who worked part-time (or not at all - a very small minority) regarded themselves as being considerably better fed than were the families of women in full-time work. This woman's father earned a little over $£ l$ as a checker on the docks, while her mother went out charring part-time:

We always had meat and potatoes and vegetables and a pudding. Lancashire people, a lot of them, didn't know what it was to sit down to a proper dinner. They would only have a pudding on a Sunday [...]. At tea-time we would have stewed apples and bread and butter and cake, home-made cakes. They always baked their own bread. ${ }^{30}$

And yet, despite the families like this one, the oral evidence gives a clear impression that working-class families in general in Preston did not enjoy such a good diet as did their Lancastrian and Barrovian counterparts; there was a greater reliance on ready-made foods, which were relatively more expensive; there was not the same range of foods as was mentioned in the two other towns; and, although it must remain a subjective impression, there was not the same general enthusiasm for mothers' meals. There appears, too, to have been substantially fewer vegetables eaten in Preston (many families mention having them only on a Sunday).

The consumption of vegetables is to a large extent connected to the existence and cultivation of allotments. It is realised that there are difficulties in estimating the importance of "living off the land"; it is for example quite impossible to calculate how many families did it, and perhaps more importantly the calorific value of the food thus obtained. There is an obvious and fundamental difference in the importance of "gathered" food for a family who possibly had one or two blackberrying expeditions per year, and another who successfully cultivated a large allotment. It is also realized that the sample is not a large enough one to be statistically valid, but no contrary evidence has emerged to suggest that it is not illustrative. There would appear to be no other way of discovering the

29 E. Schofield, "Food and Cooking of the Working-Class about 1900", in: Transactions of the Historic Society of Lancashire and Cheshire, CXXIII (1971), pp. 106, 152; M. Hewitt, Wives \& Mothers in Victorian Industry (London, 1958), pp. 74, 78-90; R. Roberts, The Classic Slum (Manchester, 1971), pp. 109-10.

${ }^{30}$ Mrs M.3.P., p. 6. 
significance of "living off the land" than by oral investigation. In this area the documentary evidence is limited to the siting of allotments on large scale Ordnance Survey Maps, and "Hints for Gardeners" in the local press.

Before the study of Preston was begun, it was assumed that as it was a much larger town than Barrow and Lancaster there would have been fewer opportunities for "living off the land". This, however, proved to be an oversimplification. Some Preston men did go fishing, and there are mentions of poachers. What, however, proved to be of interest was the unexpectedly high proportion of men in the sample, about one third, who had allotments (two of which were gardens attached to the house). This compares with a third in Barrow and a half in Lancaster. ${ }^{31}$ With the collection of the Preston data it becomes possible to look carefully at the role of the allotment in working-class life. Oral evidence has again shown some interesting differences between the three towns in this respect. There was a widespread provision of allotments throughout Barrow and Lancaster which were made available by private landowners. ${ }^{32}$ In Preston, with its very densely covered central area, the provision of allotments was limited to the peripheries of the town. ${ }^{33}$ Thus the former inhabitants of the inner city simply dismissed the question about allotments with the reply: "They did not exist." This contrasts markedly with the replies from Barrow and Lancaster, where respondents who did not have allotments themselves frequently mentioned the existence of nearby allotments. And yet there were allotments in Preston; what proved to be of significance was who held these allotments. Whereas in the Lancaster sample one half of those having allotments were unskilled men, little more than one quarter of allotment holders were unskilled workers in Preston. (There was another quarter who had begun their working lives as unskilled men, but rapidly assumed skilled or supervisory positions.) There are clear indications that in Preston the keeping of allotments was basically undertaken by the more prosper-

31 When the previous article was written, the Barrow and Lancaster data were not completed, and the towns were in any case examined together; at that point one half of the total respondents had allotments. The differential developed when the completed data were examined.

32 Lancaster also had a large estate, "The Freehold", built in the mid nineteenth century with gardens attached to the houses. Although this area had very prosperous houses and occupants, it also had worki-class streets and it would be a mistake to presume that only the wealthy lived there. Two of my respondents whose family income was under $f 1$ a week lived there. One used the garden for growing vegetables for sale in the neighbourhood; the other was a widow who was a washer-woman and used the ground as a drying area. See S. Constantine, "Amateur Gardening and Popular Recreation in the 19th and 20th Centuries", in: Journal of Social History, XIV (1980-81).

33 Three of the allotment holders technically lived outside the borough boundaries, although they regarded themselves as Prestonians. 
ous, "aspiring", members of the working class. This group was less likely to need the produce of their gardens to improve a poor diet. The Lancaster sample suggests that their allotments played a crucial part in helping the unskilled to supplement their otherwise meagre diets. The position in Barrow was different again; about one third of the allotment holders in the sample were unskilled, but it is nevertheless clear that living off the land in various forms was of importance.

This is perhaps best illustrated by looking at the two poorest areas of Barrow and Preston. Hindpool in Barrow was the area which contained the iron and steel works, and which regularly had the highest death rate of all the Barrow wards. St John's ward in Preston was reputed to be one of the poorest (and roughest) areas of the town, and usually but not always had the highest death rate. It was, however, on the south side of the town and not far from open land near the Ribble. out of the six respondents who grew up in St John's ward, only one had a garden and one other had a father who regularly went fishing. Of eight Barrow respondents who lived in Hindpool, two had allotments, two regularly went fishing or shell fish collecting, and another one kept hens in the back yard. Perhaps the most significant difference between the two areas is the almost total absence of any discussion of "living off the land" in St John's compared with the frequent mentions it received in Hindpool, where stories were recounted of buying armfuls of rhubarb, turnips and lettuces from the allotment holders (at very low prices), and there were frequent descriptions of the pigs kept on certain pieces of ground, and of how many steel workers, especially when they were out of work, went long-lining for fish on the beach. It is difficult to escape the conclusion that the inhabitants of Hindpool had a more nutritious, varied and economical diet than those of St John's ward. They certainly appear to have been healthier, as the death rates indicate. ${ }^{34}$ It is particularly significant to look at the death rates for 1908 and 1909 , when the soup kitchens in Hindpool provided two million meals during a

34 Because of the lack of continuity in the records it is not possible to cross-check each year, but the average death rate for five random years for St John (1902-04, 1910-11) was 20.65. A random five-year average for Hindpool (1898, 1900, 1904, 1906, 1908) was 14.92. Annual Reports of the Medical Officer of Health, Borough Accounts of Barrow-in-Furness, 1898, 1900, 1904, 1906, 1908; Annual Reports of the Medical Officer of Health for Preston, 1902-04, 1910-11. The Annual Reports of the Medical Officer of Health for Barrow were printed in the Borough Accounts of Barrow-in-Furness and a complete set kept in the Barrow Town Library. The Annual Reports of the Medical Officer of Health for Preston were printed separately from other reports. There is an incomplete set of them in Preston Harris Library. The Annual Reports of the Medical Officer of Health for Lancaster are in both manuscript form and in a printed version. An incomplete set is divided between the offices of the Lancaster District Community Physician and the Lancaster City Library. 
shutdown of the iron and steel works, ${ }^{35}$ and yet the population was of such a basically healthy nature that the death rate remained fairly stable and low (12.7 for 1908 and 14.2 for 1909). This should be compared with 16.35 for 1910, the nearest year available for comparison in St John's ward. ${ }^{36}$ The extent of allotment and garden keeping was obviously governed to a large degree by the availability of suitable land, but it it can also be argued that a persistent demand for allotments could mean that landowners made land available (as they did in Barrow and Lancaster). Men who kept allotments tended either to be recent migrants from a rural background, or to have jobs related to gardening (like outdoor labouring or grave-digging), or to be in an occupation with a strong tradition of self-sufficiency, like the Barrow iron workers, who brought their pig-keeping tradition with them from the West Midlands.

Working-class standards of living could be, and all too frequently were, affected by one or more members of the family drinking. The difficulties of assessing the extent of the "drinking problem" have been well described. ${ }^{37}$ Oral evidence suggests that there was considerably more steady drinking in Preston than in Lancaster and Barrow, and yet the prosecutions for drunkenness would seem to belie this. ${ }^{38}$ It is not easy to explain these discrepancies. One explanation might be that Barrow had at this period an imbalance in the population between men and women. ${ }^{39}$ Many of these "surplus" men were young, newly apprenticed, unmarried or with a wife in another town, and recently arrived in Barrow looking for work. It could well be this group, unhampered by family and neighbourhood contacts, who produced the large number of men found guilty each year of drunkenness. The oral evidence from Preston indicates a sizeable number of families where the father drank heavily and an even greater number who drank steadily. Two or three pints a night (at $2 \mathrm{~d}$ a pint) probably never resulted in trouble with the police, but represented a significant drain on a family's budget. It was also more usual in Preston than in either Barrow or

35 Barrow News, 25 July 1909.

${ }^{36}$ Annual Reports of the Medical Officer of Health Borough Accounts of Barrow-inFurness, 1908-09; Annual Report of the Medical Officer of Health for Preston, 1910.

${ }^{37}$ B. Harrison, "Drink and Sobriety in England 1815-1872", in: International Review of Social History, XIII (1967), pp. 208-09, for a critical examination of the weaknesses of using figures for prosecutions for drunkenness.

38 The average annual convictions for drunkenness in the years 1906-14 (inclusive) per 1,000 of the population were Barrow 6.6, Lancaster 1.5, Preston 2.8. Figures are taken from the Annual Licensing Statistics, 1906-14.

${ }_{39}$ The population figures were Barrow 1891 - 27,273 males, 24,439 females; 1901 31,494 males, 26,092 females; 1911 - 33,344 males, 30,396 females; Preston 1891 49,305 males, 58,268 females; $1901-51,686$ males, 61,303 females; $1911-53,915$ males, 63,173 females. 
Lancaster for women to go to pubs, and this represented a further charge on the budget. Research carried out by Miss W. A. MacKenzie in 1914 suggested that spending on alcohol reduced the calorific intake of the average family by $17.6 \%{ }^{40} \mathrm{It}$ is doubtful if it is ever possible to be so precise with our three towns, but there was in every labouring family a stark choice between on the one hand a parent drinking and on the other sufficient food for their children or indeed for themselves.

The factors which appear to have definitely affected the standards of living in Barrow, Lancaster and Preston have now been examined: the level of real wages, employment of women, the patterns of domestic expenditure, consumption and diet, and drinking habits. There are other factors which must be examined, but which, it is claimed, had little or no effect on those standards of living.

Demographic factors do not appear to have been significant in explaining why Prestonians were at a disadvantage compared with their counterparts in the other two towns. Whereas Barrow and Lancaster's families were larger than the national average of 4.73 persons used by Rowntree and taken from the 1891 census, the average Preston family was similar. ${ }^{41}$ It cannot therefore be suggested, at least on statistical evidence, that a Preston family income had more people to support than in Barrow and Lancaster (although oral evidence reveals the complexities of the responsibilities for and entitlement to a family income within the kinship group). Neither did Preston have a particularly aged population, the existence of which is usually presumed to contribute to a high death rate; it did, however, have a higher, though still small, percentage of people aged over 65 than either of the two towns and this could have contributed, although only marginally, to the difference in rates. ${ }^{42}$

40 W. A. Mackenzie, "Changes in the Standard of Living in the United Kingdom, 1800-1914", in: Economica, No 3 (1921); A. E. Dingle, "Drink and Working-Class Standards of Living in Britain 1870-1914", in: The Making of the Modern British Diet, ed. by D. J. Oddy and D. S. Miller (London, 1976), pp. 122-23.

41 Census of 1891, I, table 7: Lancaster - 5.6 persons; Barrow - 6.9 persons; Preston 4.8 persons; Census of 1901, County of Lancaster, tables 9 and 12: Lancaster -5.3 persons; Barrow - 5.5 persons; Preston - 4.6 persons; Census of 1911 , County of Lancaster, table 27: Lancaster - 4.4 persons; Barrow - 4.9 persons; Preston - 4.5 persons. The figures for 1891 should be taken to refer more accurately to household than to family size.

42 Census of 1911, County of Lancaster, table 16: Barrow - 3.7; Lancaster - 4.8; Preston - 5.6. Dr J.K. Walton, of the University of Lancaster, in his extensive studies of sea-side resorts which had very high percentages of people aged over 65 in their population, has discovered in fact that there towns had lower than average death rates. This might well suggest that high death rates were not so much affected by the demographic structure of 
Bad housing is a factor frequently mentioned as causing bad health and consequently leading to high death rates. It is, however, difficult both to define exactly what is meant by "bad" housing and it is even more difficult to compare the quality of housing in different towns. It is fairly clear that throughout this 25-year period Barrow had the best-built stock of housing. Much of it was new, i.e. built between 1890 and 1914, and very little of the older stock predated the early 1860 's. All enjoyed an indoor water supply, a water closet, and wide streets. The Board of Trade Enquiry, made in 1905, commented: "The small working-class houses in Barrow considered as a whole, represent a high degree of sanitary excellence." 43 Preston's housing stock, although continually added to, contained some very old, densely packed properties with poor ventilation and unhygienic earth privies. Yet its housing stock was continually being improved; in 1892 the Medical Officer was writing of the 20 -year effort already made by the sanitary committee either to improve or to condemn and close insanitary houses. The reports after 1900 indicate that between 1,500 and 2,000 privies were being converted to water closets every year and by 1910 the Preston Medical Officer of Health could claim that no old earth privies remained. ${ }^{44}$ It is in fact doubtful if Preston's housing was as bad as its death rate might indicate. The 1905 Board of Trade Enquiry, whilst less enthusiastic than for Barrow, supports this view in the remark that "the property in Preston defective in regard to sanitation is not considerable and probably over 90 per cent of the houses are now provided with the convenience of a water carriage system and in the remaining cases rapid progress is being made in the work of conversion." 45 Indeed in some ways Barrow and Lancaster had worse housing provision than did Preston. Both retained open middens for rubbish long after Preston had dustbins, and in both towns houses were significantly more overcrowded than were those in Preston. ${ }^{46}$ The one factor about housing which documentary evidence does not reveal but which is clear from oral evidence (again underlining the special value of this type of information), is that far more Preston respondents were both-

the population as by income levels, those who retired to the sea-side being generally prosperous.

43 Board of Trade Enquiry, op. cit., p. 66.

44 Annual Reports of the Medical Officer of Health for Preston, 1889, 1891-92, 1902-04, 1910.

45 Board of Trade Enquiry, p. 383.

46 Census of 1901 , County of Lancaster, table 7: number of persons per inhabited dwelling, Barrow - 6.7; Lancaster - 5.4; Preston - 4.7; Census of 1911, County of Lancaster, table 29: Barrow - 5.5; Lancaster - 5.1; Preston - 4.5; ibid., tables 27, 27a, 29: percentages of total population living more than 2 to a room, Barrow -8.7 ; Lancaster -3.5 ; Preston -5.6 . 
ered, both as children and as adults, with fleas, bed bugs and cockroaches, which suggests that the general hygienic level of many Preston homes was lower than in the other two towns. It can be argued that extreme cleanliness takes time, money and energy, commodities which tended to be in short supply in some Preston homes. It must be presumed that deficiences in housing and hygiene played some part in the diarrhoea death rate registered in Preston which was high compared to that in Barrow. ${ }^{47}$ Mention has already been made in several connections of the death rate, and it is argued in this article that it is a simple but effective indication of poverty; that is, the lower the standard of living (because of factors already identified), the higher the death rate within each decennial age range. In a previous study ${ }^{48}$ the present writer attempted to explain why Barrow and Lancaster, with many men ostensibly earning less than the amount which would keep them above Rowntree's poverty line, nevertheless managed to produce death rates which were lower than the average for England and Wales. In the same period, however, Preston reveals significantly higher than average general death rates, in addition to higher infant mortality rates. ${ }^{49}$

Table 6. Death rates

$\begin{array}{ccccc} & \text { Barrow } & \text { Lancaster } & \text { Preston } & \text { England \& Wales } \\ 1890-94 & 15.86 & 16.9 & 24.5 & 18.9 \\ 1895-99 & 13.96 & 14.54 & 22.5 & 17.78 \\ 1900-04 & 14.47 & 14.93 & 20.31 & 16.62 \\ 1905-09 & 12.08 & 13.10 & 17.86 & 15.00 \\ 1910-14 & 13.62 & 13.18 & 16.58 & 13.76\end{array}$

Table 7. Infant-mortality rates

Barrow Lancaster Preston England \& Wales

$\begin{array}{lllll}1891-95 & 146 & 147 & 235 & 151 \\ 1896-1900 & 162 & 172 & 235 & 156 \\ 1901-05 & 129 & 139 & 179 & 138 \\ 1906-10 & 110 & 122 & 162 & 117 \\ 1911-15 & 112 & 102 & 150 & 110\end{array}$

47 The only three years when direct comparisons can be made are 1902, 1903 and 1904. The average diarrhoea death rate in Barrow was 0,29, while the rate for Preston was 1.28. 48 Roberts, "Working-Class Standards of Living", p. 310.

49 These figures are taken from the local Medical Officers of Health Annual Reports, the 
It is certainly the case that the great epidemic diseases at the turn of the century did not affect rich and poor alike. Although the whole population may have been equally exposed to infection, the likelihood of a person sickening was greater for the poor than for the rich and, once thus infected, the likelihood of death was also higher for the poor. The infant mortality rates are a particularly clear indicator of this tendency, the rates being much higher in poorer than in prosperous districts. We may, therefore, note that there were differing death rates between the social classes, for it is a truism to local historians that in any one year death rates in the poorest areas of a town were significantly higher than in its more prosperous districts. ${ }^{50}$

It is perhaps apposite, at this point, to examine the infant-mortality rates in more detail. Historians and contemporary observers have argued throughout the nineteenth and twentieth centuries that high infant-mortality rates were not so much the result of poverty, but of mothers being employed in some full-time occupation. The evidence to support this view is well rehearsed by Margaret Hewitt. ${ }^{51}$ A contrary view has been argued by Carol Dyhouse, who claimed that there was no significant correlation between high infant-mortality rates and high percentages of women in full-time work. ${ }^{52}$ Certainly the figures for Preston, if taken only in conjunction with those for Barrow and Lancaster, would tend to support the

Registrar General Annual Reports, and the Registrar General Decennial Reports [Cd 2619 and 8002] (1905 and 1914-16). There are in fact considerable discrepancies between the death rates given by the local Medical Officer of Health for Lancaster and those given by the Registrar General. The Medical Officer of Health's average annual death rate for the years 1900-09 is 13.77 (1910 Annual Report), whilst the Registrar General's for the same period is 17.2. Although some slight variations can always be found depending on how the inter-censal population is calculated on an annual basis, these substantial differences cannot be so explained. The explanation is to be found in the Lancaster Medical Officer of Health's Report for 1910. It is clear that although there is no discrepancy in the total numbers of deaths recorded by him and by the Registrar General, there is a significant discrepancy in both the annual and the ten-year average death rates. The Medical Officer of Health refused to include in Lancaster's death rate those who had died in one of the local institutions and who was not normally a Lancaster resident: "The question of the transference of deaths for non-residents has always been the subject of much trouble in a town which contains large numbers of persons brought into it for treatment." The deaths of Lancaster residents in 1910, for example, was 555, but there were another 254 deaths of non-residents.

50 For the years 1902-04 in Preston the average death rate for the St John's ward, one of the poorest and roughest areas, was 23.69, whilst that for the neighbouring Avenham ward, which was predominantly middle-class, was 14.93. Annual Reports of the Medical Officer of Health for Preston, 1902-04.

51 Hewitt, Wives \& Mothers in Victorian Industry, op. cit., chs VIII-X.

52 C. Dyhouse, "Working-Class Mothers and Infant Mortality in England 1895-1914", in: Journal of Social History XII (1978-79). 
Table 8. Average infant-mortality rates, 1901-10

England and Wales $=127$

Textile areas

Average rate $=141$

Bolton

Bury

Rochdale

Burnley

Blackburn

Preston
148

141

133

167

148

158
Non-textile areas

Average rate $=138$

West Derby

145

Prescot

144

Wigan $\quad 166$

Warrington $\quad 140$

Barrow 119

Lancaster

Source: Registrar General Decennial Report [Cd 8002].

thesis argued by Hewitt. A rather different picture emerges when the Preston figures are examined in the context of those for the rest of Lancashire. (See Table 8. The great cities of Manchester and Liverpool have been excluded because of the rather specialised problems peculiar to them.) The registration districts have been divided into those with large percentages of women in full-time work (notably in textiles) and those with a small percentage of women in work.

It is difficult to argue from these figures that textile towns with their married women working had a noticeably higher infant-mortality rate than did those where few women were in full-time employment. The figures indeed raise more questions than they answer. Why, for example, were Barrow and Lancaster the only two towns out of the twelve with infantmortality rates below the national average? It is suggested that these figures are an indicator of poverty and that the higher the figure, the greater the degree of poverty. When we look in more detail at Preston, we find the Preston Medical Officer of Health attempting from time to time to explain Preston's high death rates by stressing the exclusion from the municipal boundaries of the predominantly middle-class areas of Fulwood and Penwortham. He believed that this left a residual poor working-class population, lacking the "improvement" in the death rates which a middle-class presence would bring, and so distorting his annual returns. It would seem, however, that the county borough of Preston had in fact a higher percentage of middle-class inhabitants than did Barrow. ${ }^{53}$ Therefore it is not

${ }^{53}$ From the occupation tables the men listed as being employed by national and local government (but excluding defence of the realm), or occupied in a professional and commercial capacity, or as living on their own means, were enumerated and these totals 
possible to "explain" Preston's high death rate in terms of the absence of a middle-class population.

It is accepted that there are difficulties in using death rates as indications of standards of living. It would be useful and interesting to have accurate and detailed data on causes of death, but these are impossible to extrapolate from the Medical Officers of Health Reports for the pre-First-WorldWar period, as the headings under which deaths are categorised are frequently changed. It would seem difficult, however, to argue for this period that a high death rate was not associated in a complex but close way with poverty. There were no dramatic periods of sudden and great poverty in Preston during this period as there were in Barrow, and to a lesser degree in Lancaster, created by strikes, lock-outs or the closure of factories, ${ }^{54}$ and there were no emergency soup kitchens remembered by Prestonians except for those of Christmas charities run for poor children. The poverty in Preston appears rather to have been chronic and grinding, and in the long term much more injurious to health.

In a very interesting study of the decline in mortality rates between 1870 and 1930, J. M. Winter argues that the most important factor in that decline was the improved nutrition, for "a sustained decline in mortality rates such as Britain experienced before the 1930s was impossible without major improvements in the quantity and quality of the per capita food intake". ${ }^{55}$ It would surely be reasonable to argue that differences in mortality rates between areas (whether different wards or different towns) can mostly be attributed to different levels of nutrition; quite simply, the better fed did not succumb to disease and die at the same rate as did those who were inadequately or unsuitably fed. Winter goes on to link improved nutrition to "a sustained and significant rise in real wages". Obviously the lower average rates for the unskilled in Preston as compared with those in Barrow and Lancaster accounted for some of the differences in the standards of living in both towns. It has been suggested that the difference in the death rates between Barrow and Preston can be attributed almost entirely to the higher average income for the whole of Barrow, resulting for a substantial proportion of craftsmen in the population with their higher than average wages. This factor, however, would not explain the differences between the

calculated as a percentage of the total number of occupied males. Census of 1891, III, table 7: Barrow - 6.4; Preston - 9.3; Census of 1901, County of Lancaster, table 35: Barrow - 5.6; Preston - 9.3; Census of 1911, County of Lancaster, tables 13 and 23: Barrow - 7.3; Preston - 9.4.

54 Roberts, "Working-Class Standards of Living", pp. 307-08.

55 J. M. Winter, "The Decline of Mortality in Britain 1870-1930", in: Population and Society in Britain 1850-1980, ed. by M. Drake and T. Barker (London, 1982). 
death rates for Lancaster and Preston because there was not a high percentage of skilled men in Lancaster at this period.

Thus we can see that there were a number of factors at work in the three towns which affected working-class standards of living. Wages were of the utmost importance, but standards of living cannot be examined simply by constructing wage indices. The example of Preston illustrates how living standards were adversely affected by the existence of low real wages, but evidence from all three towns suggests that the strategies adopted by working-class families to ensure their survival were also of critical importance. The evidence also indicates the interdependence of many of the factors affecting working-class standards of living. Not all strategies were available to all families, and some were more successful than others. It is hoped that this article has illustrated that the various strategies adopted by working-class families to balance their budgets were of great importance not only in establishing their own, but also both positively and negatively (as in the case of married women's wages) their communities' standards of living. 